Atmos. Meas. Tech. Discuss., 2, 2027-2054, 2009

www.atmos-meas-tech-discuss.net/2/2027/2009/

(C) Author(s) 2009. This work is distributed under

the Creative Commons Attribution 3.0 License.

Development and application of a new mobile LOPAP instrument

R. Häseler et al.

\section{Development and application of a new mobile LOPAP instrument for the measurement of HONO altitude profiles in the planetary boundary layer}

Title Page

Abstract Introduction

Conclusions

References

Tables

Figures

R. Häseler, T. Brauers, F. Holland, and A. Wahner

ICG-2, Forschungszentrum Jülich, 52425 Jülich, Germany

Received: 6 August 2009 - Accepted: 17 August 2009 - Published: 28 August 2009

Correspondence to: T. Brauers (th.brauers@fz-juelich.de)

Published by Copernicus Publications on behalf of the European Geosciences Union.

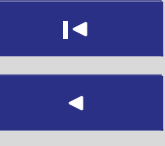

$\Delta \mathbf{I}$

Back

Close

Printer-friendly Version

Interactive Discussion 


\section{Abstract}

The LOPAP (long path absorption) technique has been shown to be very sensitive for the detection of nitrous acid (HONO) in the atmosphere. However, current instruments were mainly built for ground based applications. Therefore, we designed a new LOPAP

5 instrument to be more versatile for mobile measurements and to meet the requirements for airborne application. The detection limit of the new instrument is below $1 \mathrm{ppt}$ at a time resolution of 5 to $7 \mathrm{~min}$. As a first test, the instrument was successfully employed during the ZEPTER-1 campaign in July 2007 on board of the Zeppelin NT airship. During 15 flights on six days we measured HONO concentration profiles over southwest 10 Germany, predominantly in the range between $100 \mathrm{~m}$ and $650 \mathrm{~m}$ above ground level. On average, a mixing ratio of 34 ppt was observed, almost independently of height. Within a second campaign, ZEPTER-2 in fall 2008, higher HONO mixing ratios were observed in the Lake Constance area.

\section{Introduction}

15 Nitrous acid (HONO) is an important precursor for $\mathrm{OH}$ radicals in the atmosphere (e.g. Finlayson-Pitts and Pitts, 1999) since it is quickly photolyzed in the sunlight:

$\mathrm{HONO}+h v \rightarrow \mathrm{OH}+\mathrm{NO}$

The lifetime of HONO is in the order of 20 min around noon in summer. Recent studies (Zhou et al., 2002; Alicke et al., 2003; Kleffmann et al., 2005; Acker et al., 2006; Su et al., 2008) showed the significant contribution of HONO photolysis to the OH production rate during the entire day. In the gas phase $\mathrm{HONO}$ is formed by the reaction of $\mathrm{OH}$ with NO

$\mathrm{OH}+\mathrm{NO}+\mathrm{M} \rightarrow \mathrm{HONO}+\mathrm{M}$

Besides the gas phase source of HONO (R2) heterogeneous sources on surfaces exist,

but the picture of the heterogeneous HONO source is not conclusive at the moment 2028

AMTD

2, 2027-2054, 2009

\section{Development and application of a new mobile LOPAP instrument}

R. Häseler et al.

\section{Title Page}

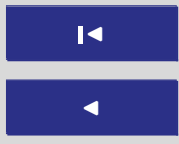

$\Delta$

Back

○

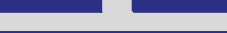

Full Screen / Esc

Printer-friendly Version

Interactive Discussion 
(e.g. Kleffmann, 2007). However, lacking understanding of the formation processes of $\mathrm{HONO}$ makes it necessary to accurately measure $\mathrm{HONO}$ when the budget of $\mathrm{OH}$ or $\mathrm{NO}_{\mathrm{x}}$ is considered.

Before 2000, HONO measurements were mostly performed using Differential Op5 tical Absorption Spectroscopy (DOAS) (e.g. Platt et al., 1980; Winer and Biermann, 1994) or different types of denuders (e.g. Harrison et al., 1996; Febo et al., 1996; Neftel et al., 1996). In 1999, LOng PAth absorPtion (LOPAP) was introduced by Heland et al. (2001) as a new sensitive in situ technique. The LOPAP instrument was applied in field campigns (e.g. Kleffmann et al., 2003, 2005) and laboratory studies 10 (e.g. Bröske et al., 2003; Rohrer et al., 2005; Stemmler et al., 2007) The instruments were improved by Kleffmann and co-workers and successfully compared to the DOAS technique (Kleffmann et al., 2006). Now it is marketed through QUMA Elektronik \& Analytik GmbH (Wuppertal, Germany). However, these instruments were not designed for mobile applications. Therefore, we re-engineered the LOPAP in order to meet the 15 stringent approval requirements for airborne operation.

The LOPAP technique can be explained by a simple flow chart presented in Fig. 1. In a first step the air is pumped through two sampling coils connected in series where the HONO is stripped into the liquid phase. The first coil (channel 1) removes HONO nearly quantitatively from the gas phase but only a small fraction of interfering species.

20 The second coil (channel 2) samples the same fraction of the interfering species but only the remaining small amount of HONO. Using the difference of the signals of channels 1 and 2 strongly reduces the influence of interfering species. The stripping solution (S1) consists of $0.06 \mathrm{M}$ sulfanilamide in a $1 \mathrm{M} \mathrm{HCl}$ solution. HONO instantaneously forms a diazonium salt with the stripping solution. The air is separated from the liquid 25 and the solutions are pumped into two independent mixing volumes where a $0.8 \mathrm{mM}$ solution of $\mathrm{N}$-(1-naphthyl)ethylenediamine-dihydrochloride (S2) is injected to form the azo dye. The concentration of the azo dye is then detected by optical absorption. The absorption cells for both channels consist of long length Teflon tubing, acting as liquid core waveguide (LCW). Visible light is sent through the tubing and detected by two

AMTD

2, 2027-2054, 2009

\section{Development and application of a new mobile LOPAP instrument}

R. Häseler et al.

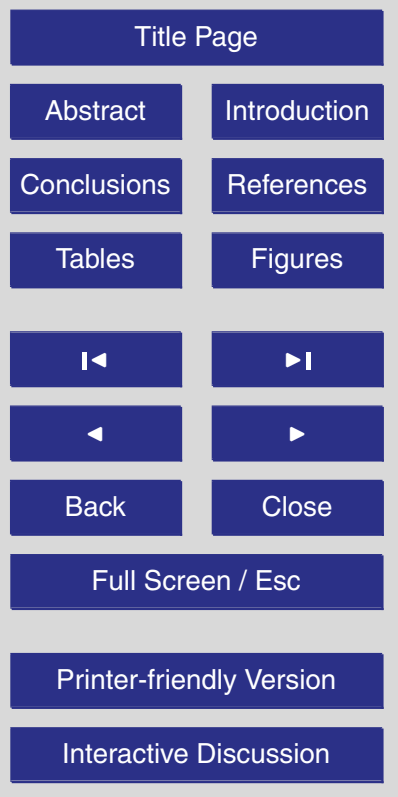

Interactive Discussion 
mini-spectrometers.

In this study, we present the outline of a new, improved LOPAP instrument which was certified for airborne applications. We also show the first direct measurements of HONO performed aboard an airship (Zeppelin-NT) using the new instrument which 5 we call LOPAP-Z. We sampled various vertical profiles of HONO over Lake Constance and over mainly forested areas in southern Germany. The budget of HONO and its relevance for the $\mathrm{OH}$ photochemistry will be discussed in a forthcoming paper (Brauers et al., 2008.)

\section{The new LOPAP-Z instrument}

Based on the experience with the current LOPAP-3 instruments (marketed by QUMA) and forced by the requirements for airborne application, we redesigned the instrument, but we retained the LOPAP concept (cf. Fig. 1). A ruggedized sampling unit, the use of certified airworthy materials, and the separation of the chemistry part from electronics were required to meet the flight requirements. Additional modifications were demanded 15 by the limited power and space aboard the airship. The entire instrument (Fig. 2) was housed in a 19" rack of $56 \mathrm{~cm} \times 60 \mathrm{~cm} \times 100 \mathrm{~cm}$ (width $\times$ depth $\times$ height).

\subsection{Hardware modifications and improvements}

The subsequent list compares the hardware of the LOPAP-Z to the instrument described by Kleffmann et al. (2006).

- Optimized and ruggedized sampling unit for mobile applications: the new sampling unit (Fig. 3) consists of a stripping coil which is integrated in a solid glass cylinder having the sampling inlet on one end surface and all connectors on the other surface. The entire sampling unit is made of glass. The stripping coil of $17 \mathrm{~cm}$ length, and $2 \mathrm{~mm}$ i.d. is similar to the original design, also providing a high sampling efficiency for HONO. In order to minimize sampling artifacts the length

AMTD

2, 2027-2054, 2009

\section{Development and application of a new mobile LOPAP instrument}

R. Häseler et al.

\section{Title Page}

\section{Full Screen / Esc}

Printer-friendly Version

Interactive Discussion 
of the sampling inlet is only $5 \mathrm{~cm}$. To avoid photochemical reactions in the gas and liquid phase inside the sampling unit it is shielded against daylight. The zero air is internally injected by a glass line directly into the inlet line of the stripping coil. For flight operation, the sampling unit was designed to have a low weight and small size. The small size minimizes the drag from the wind when the sampling unit sticks out of the window of the Zeppelin (cf. Fig. 5). Good thermal insulation reduced the requirements for the cooler.

- Thermoelectric Peltier coolers: the sampling loop of the LOPAP-3 was kept at a constant temperature by a laboratory compressor liquid bath cooler. For LOPAP$Z$ we replaced the cooler by a small-sized $(300 \mathrm{~mm} \times 152 \mathrm{~mm} \times 105 \mathrm{~mm})$ air-toliquid Peltier cooler (LA-160-24-02-00-00, Supercool, Sweden). An additional airto-air Peltier cooler (LA-160-24-22-00-00, Supercool, Sweden) is used to control the temperature in the chemistry unit.

- Improved optics: similar to the instrument described by Kleffmann et al. (2006) we used white light-emitting LEDs (Lumileds, Typ: LUXEON V star white, LXHLLW6C) instead of halogen lamps as in the original design of Heland et al. (2001). The light from these diodes is transferred to the absorption path by fiber optics (OZ-Optics, Multimode Fiber QMMJ-55-UVVIS-600/660-3-x). Different from the original design we use small lenses to focus the light into the absorption path (liquid core waveguide LCW) made of Teflon tubing (AF 2400). This separates the fiber from the liquid and reduces the risk of leaks. The size of the dead volume is not affected. We also replaced the spectrometers (Ocean Optics, SD 2000) by new USB spectrometers (OMT, ctf-60) which provide a high stability and low noise.

- Electronic I/O interface: the components of the LOPAP-Z (with exception of the spectrometers), are interfaced through one I/O board. This board provides the data and settings of the flow controller, valves, pumps, LEDs, and temperatures

\section{AMTD}

2, 2027-2054, 2009

\section{Development and application of a new mobile LOPAP instrument}

R. Häseler et al.

\section{Title Page}

Abstract Introduction

Conclusions References

Tables Figures

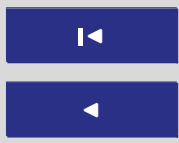

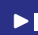

Back Close Full Screen / Esc

Printer-friendly Version

Interactive Discussion 
to the single board computer, where these data are simultaneously recorded with every spectrum.

- Separated units: the different modules of the instrument were separated into three units: 1. electronics unit containing the power supplies for all components, the spectrometers and LEDs, and the interface and computer boards, 2. supply of chemicals in a spill proof containment, and 3. the thermostatic liquid chemistry unit containing the pumps, flow controllers, and optical paths (see setup in Fig. 2). All units are in enclosed containments to meet the certification requirements.

- Low weight, low power consumption: the total weight including a set of chemicals is $75 \mathrm{~kg}$. The power consumption of the entire instrument during operation is $250 \mathrm{~W}$. The peak power reaches $800 \mathrm{~W}$ during startup and heavy cooling.

- Certification for air-borne operation: the instrument was certified by Zeppelin Luftfahrttechnik for mechanical stability, electrical safety, fire safety, and safe containment for chemicals and waste.

\subsection{The LOPAP-Z software and evaluation procedure}

The new hardware components required new software for the automatic operation. We developed a $\mathrm{C}++$ program (AICONS) which controls all components (spectrometers, mass flow controllers, pumps, thermostats) through one interface (Ehmer, 2009). The data is automatically stored in netCDF ${ }^{1}$ format. However, during the campaigns described in the result section of this paper we used the aSpect2.8 software (OMT) to record the spectra since the Aicons software was not yet fully operational.

The procedure for converting the measured absorption spectra into HONO mixing ratios starts with the calculation of the relative absorbance $A=\log \left(I_{650 \mathrm{~nm}} / I_{550 \mathrm{~nm}}\right)$ for

\footnotetext{
${ }^{1}$ NetCDF (network Common Data Form) software libraries and data formats, see http://www. unidata.ucar.edu/software/netcdf/
}

AMTD

2, 2027-2054, 2009

\section{Development and application of a new mobile LOPAP instrument}

R. Häseler et al.

\section{Title Page}

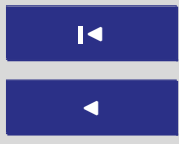

$>$ I

Back

Close

Full Screen / Esc

Printer-friendly Version

Interactive Discussion 
both channels, where $650 \mathrm{~nm}$ and $550 \mathrm{~nm}$ are the measurement wavelength and reference wavelength, respectively. In the next step we determine the zero point absorption for both channels from frequent measurements of synthetic air. These values are used to correct the absorbance in both channels. In a third step, we convert the absorbance 5 into $\mathrm{NO}_{2}^{-}$concentrations using the flow rates and the calibration curve independently determined using a liquid standard. Finally, the HONO mixing ratio is calculated from the air flow rate, the sampling efficiency, and the $\mathrm{NO}_{2}^{-}$concentrations of both channels. We use gaussian error propagation to calculate the systematic error.

The spectra were recorded at rate of $5 \mathrm{~s}$. However, the time resolution of the instru10 ment is between $5 \mathrm{~min}$ and $8 \mathrm{~min}$ depending on the flow rate of the liquids through the absorption path. The time resolution was independently determined when zero point measurement were started and ended. For this study we converted the $5 \mathrm{~s}$ original data to $5 \mathrm{~min}$ averages which are shown in the figures.

\subsection{Characterization by laboratory tests}

15 Before and after the field campaigns some important parameters of the LOPAP-Z were determined by a number of tests in the laboratory.

- Water dependence of sampling: a critical parameter for the conversion of signals in to HONO mixing ratios is the flow rate of the chemical through the sampling unit. When the sampled air is dry (i.e. at low relative humidity with respect to the temperature in the sampling unit) a small fraction of water in the flow of chemicals in channel 1 is evaporated into the gas phase and thus changes the concentration of the reactants for the subsequent analysis. Due to changing water content during the flight operation (i.e. change in altitude and air mass) we calculated a time dependent factor from the absolute humidity during the flights.

- Determination of the sampling efficiency: for the current sampling unit we determined the sampling efficiency at three different flow rates $(1000 \mathrm{ml} / \mathrm{min}$, $1500 \mathrm{ml} / \mathrm{min}$, and $2000 \mathrm{ml} / \mathrm{min})$. The HONO source was a thermostated $\left(15^{\circ} \mathrm{C}\right)$ 2033

\section{AMTD}

2, 2027-2054, 2009

\section{Development and application of a new mobile LOPAP instrument}

R. Häseler et al.

\section{Title Page}

\section{Full Screen / Esc}

Printer-friendly Version

Interactive Discussion 
wash bottle with $200 \mathrm{ml} \mathrm{H}_{2} \mathrm{SO}_{4}(0.02 \mathrm{~N})$ and $20 \mathrm{ml} \mathrm{NaNO} \mathrm{N}_{2}(0.2 \mathrm{mg} / \mathrm{l})$. During the Zeppelin flights the flow rate was set to $1500 \mathrm{ml} / \mathrm{min}$ which resulted in the best sensitivity. We used a sampling efficiency of $95.14 \%$ for the evaluation of the data.

- Intercomparison to previous instruments: as part of the performance tests of the new instrument we performed an intercomparison to the existing LOPAP-3 instrument. We sampled air through an inlet line through the window of the lab and split the air through a T-connector into the instruments.

The result of the pre-campaign laboratory intercomparison is shown in Fig. 4. Both instruments agree within the error of the single instrument. A disadvantage of this test was the sampling configuration which introduced a Teflon line before the sampling loop inlet. It is planned, however, to repeat this test under the well controlled conditions of the atmosphere simulation chamber SAPHIR at Jülich.

- Stability, precision, detection limit, and accuracy: during the laboratory measurement period, we tested the stability of the instrument reading when fed with synthetic air. Typically we observed a combination of signal drift and noise which was in the range of $1 \mathrm{ppt}$ and below. From these measurements we obtained a detection limit of $0.7 \mathrm{ppt}(2-\sigma)$ for a time resolution of $5 \mathrm{~min}$. The precision is $1.2 \mathrm{ppt}$ (at $100 \mathrm{ppt} \mathrm{HONO}$ mixing ratio). The measurement range of the instrument can be varied by the length of the absorption tubes and by the use of different absorption wavelengths for the evaluation (Heland et al., 2001). In this study we used an optical path length of $2.9 \mathrm{~m}$. From the calibrations we calculate an accuracy of $6 \%$ which represents the 2- $\sigma$ error of the sensitivity.

\section{The Zeppelin airship and the ZEPTER campaigns}

25 The LOPAP-Z instrument was designed and setup in the first half of 2007. During two field campaigns, it was employed on a Zeppelin NT airship for 15 flights in July 2007

\section{Development and application of a new mobile LOPAP instrument}

R. Häseler et al.

\section{Title Page}

\section{Full Screen / Esc}

Printer-friendly Version

Interactive Discussion 
and 25 flights in October/November 2008.

\subsection{Zeppelin NT airship}

The Zeppelin NT semi-rigid airship is an engine-driven, near-equilibrium, steerable aircraft. A vectored thrust propulsion system can give additional lift and an accurate steer-

5 ing capability at low speed. Three engines provide the power for the airship. The airship is build around a framework of triangular carbon-fibre frames connected by aluminum longerons. The cabin, empennage, and engines are mounted on this rigid structure. The pressurized envelope of the Zeppelin NT, which is made of a multi-layer laminate fabric, encloses a volume of $8450 \mathrm{~m}^{3}$. The total dimensions of the Zeppelin NT are $1075.0 \mathrm{~m}$ length, $19.5 \mathrm{~m}$ width, and $17.4 \mathrm{~m}$ height (Fig. 5). The airship body consists of a carrier gas cell which is filled with non-flammable helium and two internal air cells (ballonets). The gondola of the Zeppelin carried most of the scientific instruments. The seats were removed to give space for five 19" standard racks. Electrical power is supplied by the airship for the instruments (entirely $220 \mathrm{~A}$ at $28 \mathrm{~V} \mathrm{DC}$ ). A detailed description of the Zeppelin-NT and its capabilities for scientific explorations will be described by Oebel et al. (2009).

\subsection{ZEPTER campaigns}

The measurements during the ZEPTER campaigns were performed during 18 flights in July 2007 and 25 flights in October/November 2008 (see Tables 1 and 2). The first campaign (ZEPTER-1) was intended as a first test for the instruments and the integration aboard the airship. However, it was also thought as an addition to the field campaign COPS-TRACKS (Wulfmeyer and Behrendt, 2007 ). The second campaign was a test campaign for the $\mathrm{OH}$ and $\mathrm{HO}_{2}$ LIF instrument. In addition, these flights were embedded into a program of measurements above different land cover. It was accompanied

The LOPAP-Z instrument participated in all flights of both campaigns, however,

AMTD

2, 2027-2054, 2009

\section{Development and application of a new mobile LOPAP instrument}

R. Häseler et al.

\section{Title Page}
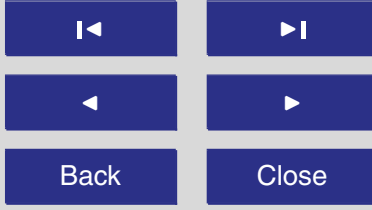

Full Screen / Esc

Printer-friendly Version

Interactive Discussion 
during flights F01, F04, and F15 in 2007 and F12 and F23 in 2008 no data were recorded due to technical problems. The flights in 2007 were carried out during daytime only (Table 1) during ZEPTER-1 while ZEPTER-2 had night flights as well (Table 2). The detailed flight tracks and the instrumentation during the flights are available 5 from http://zeppelin.fz-juelich.de.

\section{Exemplary measurements of HONO}

\subsection{ZEPTER-1}

The ZEPTER-1 campaign in July 2007 was the first test not only for the new LOPAP-Z instrument but also for the integration of all instruments aboard the Zeppelin NT airship 10 (Oebel et al., 2009). Therefore, the flight tracks and maneuvers were often determined based on technical issues, rather than atmospheric chemistry issues. Here, we present all measured HONO data in 5 min time resolution. The HONO measurements were partly accompanied by simultaneous recordings of $\mathrm{NO}_{x}, \mathrm{O}_{3}, \mathrm{HCHO}, \mathrm{CO}$, VOCs, photolysis frequencies, and other parameters, which will be published separately.

15 During 15 flights we measured HONO mixing ratios with the LOPAP-Z (Fig. 6) mainly covering the range from $100 \mathrm{~m}$ to $600 \mathrm{~m}$ height above the ground, corresponding to approximately $300 \mathrm{~m}$ to $900 \mathrm{~m}$ above sea level. The flights F02-F09 were performed around Friedrichshafen, Lake Constance area. Flight F05, during afternoon hours, showed low, almost constant values (30 ppt) from $50 \mathrm{~m}$ to $750 \mathrm{~m}$. Flight F08, performed in early morning hours showed values all below 100 ppt. Interestingly, the highest values of $100 \mathrm{ppt}$ were observed in the first ascent of the airship, while later profiles are at 30 ppt only. This effect is probably driven by sunlight photolyzing HONO via reaction $\mathrm{R} 1$. The other profiles in the Friedrichshafen area are characterized by higher HONO concentrations. The flights F01-F08 were not accompanied by full sets of other measurements since the flights were mainly used for integration tests. The flights were carried out at very similar temperatures from $286 \mathrm{~K}$ to $296 \mathrm{~K}$. Two transfer flights

\section{AMTD}

2, 2027-2054, 2009

\section{Development and application of a new mobile LOPAP instrument}

R. Häseler et al.

\section{Title Page}

Abstract Introduction

Conclusions

Tables

References Figures

14

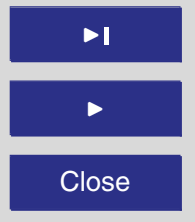

Back 
(F10 and F18) from Friedrichhafen to Baden Airpark went along the valleys of the Black Forest. While F18 shows low values throughout the flight, F10 exhibit one large spike (exceeding the $0.5 \mathrm{ppb}$ range of Fig. 6) which was not seen in other trace gas measurements. However, the inlet for the $\mathrm{NO}_{\mathrm{x}}, \mathrm{O}_{3}$, and $\mathrm{CO}$ instruments was at the 5 top platform , approximately $20 \mathrm{~m}$ above the inlet of the LOPAP-Z. The flights out of Baden airpark (F11-F17) were intended to study the photochemistry over different places as a contribution to the COPS-TRACKS project. The values observed here are well below 200 ppt for all flights. The spike in F17 corresponds to high values in the $\mathrm{NO}_{\mathrm{x}}$ measurements as well and points to a plume of polluted air.

$10 \quad$ Figure 7 presents the summary of all data recorded with the LOPAP-Z instrument as a function of the height of the airship above ground. The majority of the measurements were made between $100 \mathrm{~m}$ and $600 \mathrm{~m}$. If the data are analyzed in $50 \mathrm{~m}$ height intervals the median mixing ratio does not show a large variation between $100 \mathrm{~m}$ and $650 \mathrm{~m}$ where the number of data points per interval is high enough to provide a meaningful 15 analysis of the distribution within the $50 \mathrm{~m}$ interval. We find that the median varies between 30 ppt and 50 ppt indicating no significant altitude dependence in this range of altitudes.

\subsection{ZEPTER-2}

The ZEPTER-2 campaign took place from 17 October 2008 to 8 November 2008 out of Friedrichhafen airport (FDH). All flights were within $100 \mathrm{~km}$ from $\mathrm{FDH}$, which is the maximum range for the airship for a round-trip with the payload described in Table 2. The focus of the campaign was twofold: firstly, for integration and initial testing of the instruments aboard the airship and secondly, on the influence of different surfaces (forests, agricultural areas) on the composition and chemistry of the atmospheric boundary layer. The tests flights (F01 to F07) were operated with a reduced set of instruments intended to integrate the $\mathrm{HO}_{x}$ instruments (see Table 2). The LOPAP-Z was successfully operated aboard the Zeppelin NT, during the ZEPTER-2 campaign and was able to deliver data for 23 out of 25 flights (Fig. 8).

\section{Development and application of a new mobile LOPAP instrument}

R. Häseler et al.

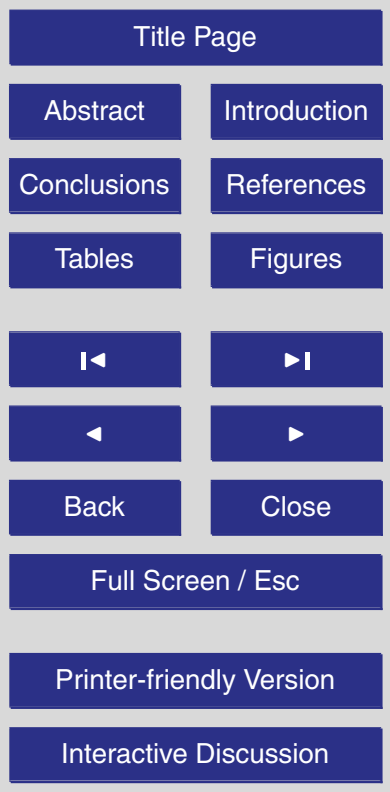


Compared to July 2007 the values are generally higher, often between 100 ppt and 200 ppt. Several data sets show a pronounced vertical profile, i.e. F02, F04, F07, and F16. These flights were carried out around noon when the HONO lifetime is relatively short due to photolysis. However, at this time of the year, the HONO photolysis is 5 about $30 \%$ lower than in July. Several data sets show spikes even extending the range of Fig. 8.

An overview on all data sets (Fig. 9) shows the enormous variation. The majority of the data is between $70 \mathrm{ppt}$ and $300 \mathrm{ppt}$, with a median of $150 \mathrm{ppt}$, well above the range found in the ZEPTER-1 campaign. The box-whisker plot indicates an average profile 10 which decreases from $200 \mathrm{ppt}$ at $100 \mathrm{~m}$ altitude to $\approx 100 \mathrm{ppt}$ at $700 \mathrm{~m}$.

In contrast to the 2007 campaign, we also conducted flights after sunset. The data were separated in two subsets selected by the solar zenith angle (SZA) being less or greater than $90^{\circ}$. The frequency distributions (Fig. 10) show no significant difference between the subsets. Both exhibit a similar nearly log-normal distribution of the data centered around 150 ppt. The majority of the night data were recorded in the evening, shortly after sunset. Altitude profiles obtained during the entire night would be a worthwhile extension in order to compare these to ground based measurement which generally exhibit nighttime maxima.

\section{Conclusions and outlook}

20 A new mobile LOPAP-Z instrument, certified for flight operation, was designed and tested. It was successfully operated during 38 flights aboard an airship. For the first time the airship Zeppelin NT was equipped with a comprehensive set of instruments to investigate the photochemical state of the planetary boundary layer. The measured HONO mixing ratios in the altitude range between $100 \mathrm{~m}$ and $950 \mathrm{~m}$ (above ground)

were between the detection limit of $5 \mathrm{ppt}$ and a maximum of $1 \mathrm{ppb}$. However, for the summer 2007, the median altitude profile between $100 \mathrm{~m}$ and $1000 \mathrm{~m}$ was almost constant at $35 \mathrm{ppt}$ while in the fall 2008 the values were apparently higher. The presented
AMTD

2, 2027-2054, 2009

\section{Development and application of a new mobile LOPAP instrument}

R. Häseler et al.

\section{Title Page}

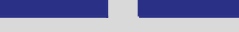

\section{Full Screen / Esc}

Printer-friendly Version

Interactive Discussion 
HONO mixing ratios and their variability show the importance of direct HONO measurements when the fast photochemistry of $\mathrm{HO}_{\mathrm{x}}$ radicals is studied.

The instrument was designed to operate reliably and to meet the safety requirements of mobile operations, e.g. by clearly separating liquids from electronics into sealed 5 compartments. The concepts and the instrument layout presented here might also be applied to instruments measuring other species. In the meantime LOPAP has been extended to measure $\mathrm{HNO}_{3}$ (Kleffmann et al., 2007) and $\mathrm{NO}_{2}$ (Villena Tapia et al., 2008).

\section{Appendix A}

10

\section{Flight information}

The flights of the ZEPTER campaigns were carried out in south west Germany. Tables 1 and 2 provide an overview on the flights and the general concept. Detailed data on the instrumentation of the Zeppelin, flight tracks, and meteorological conditions are 15 available from the campaigns' web site at http://zeppelin.fz-juelich.de. Here, we only give a general outline of the flights.

The flight plans were based on status and availability of instruments and the weather conditions, i.e. the airship cannot be operated at low visibility, high wind speeds, or in thunder or hail storms. The duration of the flights was between $1 \mathrm{~h}$ and $4 \mathrm{~h}$. in 20 most cases the measurements close to the airport (below $100 \mathrm{~m}$ height) were strongly influenced by local pollution. Those measurements are not included.

Acknowledgements. The authors thank all participants of the ZEPTER campaigns, namely A. Hofzumahaus and F. Rohrer for good collaboration. We thank J. Ehmer for programming support and the AICONS software. The authors wish to thank the crew of the ZLT Zeppelin Luftschifftechnik $\mathrm{GmbH}$ and the Deutsche Zeppelin-Reederei $\mathrm{GmbH}$ for their helpful cooperation and their support of the field campaigns. Financial support of BMBF is acknowledged (Förderkennzeichen 01LG0602 and 01LP0802A).

AMTD

2, 2027-2054, 2009

\section{Development and application of a new mobile LOPAP instrument}

R. Häseler et al.

\section{Title Page}

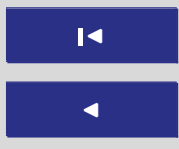

$>$ I

\section{Full Screen / Esc}

Printer-friendly Version

Interactive Discussion 


\section{References}

Acker, K., Möller, D., Wieprecht, W., Meixner, F., Bohn, B., Gilge, S., Plass-Dülmer, C., and Berresheim, $\mathrm{H}$.: Strong production of $\mathrm{OH}$ from $\mathrm{HNO} 2$ at a rural mountain site, Geophys. Res. Lett., 33, L02 809, doi:10.1029/2005GL024643, 2006. 2028

5 Alicke, B., Geyer, A., Hofzumahaus, A., Holland, F., Konrad, S., Pätz, H., Schäfer, J., Stutz, J., Volz-Thomas, A., and Platt, U.: OH formation by HONO photolysis during the BERLIOZ experiment, J. Geophys. Res., 108, 8247-8263, doi:10.1029/2001JD000579, 2003. 2028

Brauers, T., Häseler, R., Bohn, B., Holland, F., Rohrer, F., Tillmann, R., and Wahner A.: Measurement of $\mathrm{HONO}$ altitude profiles in the planetary boundary layer, manuscript in preparation, 2009.

Bröske, R., Kleffmann, J., and Wiesen, P.: Heterogeneous conversion of $\mathrm{NO}_{2}$ on secondary organic aerosol surfaces: A possible source of nitrous acid (HONO) in the atmosphere?, Atmos. Chem. Phys., 3, 469-474, 2003, http://www.atmos-chem-phys.net/3/469/2003/. 2029

15 J. Ehmer: AICONS for LOPAP (Automated Instruments Control Software): Ein Programm zur automatisierten Messdatenerfassung und Steuerung des LOPAP Messinstruments mit Hilfe einer graphischen Benutzeroberfläche; Bachelor Thesis, FH Jülich, 2009(in German).

Febo, A., Perrino, C., and Allegrini, I.: Measurement of nitrous acid in Milan, Italy, by DOAS and diffusion denuders, Atmos. Environ., 30, 3599-3609, 1996. 2029

20 Finlayson-Pitts, B. J. and Pitts, J. N.: Chemistry of the Upper and Lower Atmosphere - Theory, Experiments and Applications, Academic Press, San Diego, 1999. 2028

Harrison, R., Peak, J., and Collins, G.: Tropospheric cycle of nitrous acid, J. Geophys. Res., 30, 14429-14439, doi:10.1029/96JD00341, 1996. 2029

Heland, J., Kleffmann, J., Kurtenbach, R., and Wiesen, P.: A new instrument to measure 25 gaseous nitrous acid (HONO) in the atmosphere, Environ. Sci. Technol., 35, $3207-3212$, doi:10.1021/es000303t, 2001. 2029, 2031, 2034, 2045

Kleffmann, J.: Daytime sources of nitrous acid (HONO) in the atmospheric boundary layer, Chemphyschem, 8, 1137-1144, doi:10.1002/cphc.200700016, 2007. 2029

Kleffmann, J., Kurtenbach, R., Lorzer, J., Wiesen, P., Kalthoff, N., Vogel, B., and Vogel, H.: Measured and simulated vertical profiles of nitrous acid - Part I: Field measurements, Atmos. Environ., 37, 2949-2955, 2003. 2029

Kleffmann, J., Gavriloaiei, T., Hofzumahaus, A., Holland, F., Koppmann, R., Rupp, L.,

\section{Development and application of a new mobile LOPAP instrument}

R. Häseler et al.

\section{Title Page}


Schlosser, E., Siese, M., and Wahner, A.: Daytime formation of nitrous acid: a major source of $\mathrm{OH}$ radicals in a forest, Geophys. Res. Lett., 32, L05818, doi:10.1029/2005GL022524, 2005. 2028, 2029

Kleffmann, J., Lörzer, J., Wiesen, P., Kern, C., Trick, S., Volkamer, R., Rodenas, M., and

$5 \quad$ Wirtz, K.: Intercomparison of the DOAS and LOPAP techniques for the detection of nitrous acid (HONO), Atmos. Environ., 40, 3640-3652, doi:10.1016/j.atmosenv.2006.03.027, 2006. 2029, 2030, 2031

Kleffmann, J., Gavriloaiei, T., Elshorbany, Y., Rodenas, M., and Wiesen, P.: Detection of nitric acid (HNO3) in the atmosphere using the LOPAP technique, J. Atmos. Chem., 58, 131-149, 2007. 2039

Kottmeier, C. and Höller, H. with contributions by Beheng, K., Raschke, E., Quante, M., Rockel, B., Lüpkes, C., Smit, H., and Hofzumahaus A.: Transport and Chemical Conversion in Convective Systems (TRACKS) Conception of a Three-stage Large-scale Experiment Section Atmosphere and Climate HGF Research Area Earth and Environment, http://www.imk.uni-karlsruhe.de/download/tracks-eng-150dpi.pdf, 2008.

Neftel, A., Blatter, A., Hesterberg, R., and Staffelbach, T.: Measurements of concentration gradients of $\mathrm{HNO} 2$ and $\mathrm{HNO} 3$ over a semi-natural ecosystem, Atmos. Environ., 30, 30173025, doi:10.1016/1352-2310(96)00011-8, 1996. 2029

Oebel, A., Hofzumahaus, A., Holland, F., Broch, S., Raak, D., Rohrer, F., Bohn, B., Wahner, A., Gritzbach, R., and Steinlein, K.: Zeppelin NT: A new neasurement platform for studies of photochemistry in the lower troposphere, Atmos. Meas. Techn., in preparation, 2009. 2035, 2036

Platt, U., Perner, D., Harris, G., Winer, A., and Pitts Jr, J.: Observation of nitrous acid in an urban atmosphere by differential optical absorption, Nature, 285, 312-314, doi:10.1038/285312a0, 1980. 2029

Rohrer, F., Bohn, B., Brauers, T., Brning, D., Johnen, F.-J., Wahner, A., and Kleffmann, J.: Characterisation of the photolytic HONO-source in the atmosphere simulation chamber SAPHIR, Atmos. Chem. Phys., 5, 2189-2201, 2005, http://www.atmos-chem-phys.net/5/2189/2005/. 2029

30 Stemmler, K., Ndour, M., Elshorbany, Y., Kleffmann, J., D'Anna, B., George, C., Bohn, B., and Ammann, M.: Light induced conversion of nitrogen dioxide into nitrous acid on submicron humic acid aerosol, Atmos. Chem. Phys., 7, 4237-4248, 2007, http://www.atmos-chem-phys.net/7/4237/2007/. 2029

\section{Development and application of a new mobile LOPAP instrument}

R. Häseler et al.

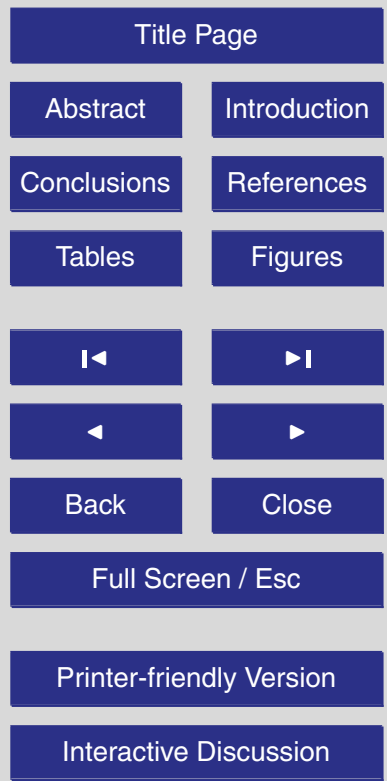


Su, H., Cheng, Y. F., Shao, M., Gao, D. F., Zeng, L. M., Slanina, J., Zhang, Y. H., and Wiedensohler, A.: Nitrous acid (HONO) and its daytime sources at a rural site during the 2004 PRIDE-PRD experiment in China, J. Geophys. Res., 113, D14312, doi: 10.1029/2007JD009060, 2008. 2028

5 Villena Tapia, G., Bejan, I., Wiesen, P., and Kleffmann, J.: Intercomparison of a new ultrasensitive NO2-LOPAP against commercial $\mathrm{NO}_{2}$ instruments and the FTIR technique, poster presented at EGU General Assembly, Geophysical Research Abstracts, Vol. 10, EGU2008A-07742, 2008 SRef-ID: 1607-7962/gra/EGU2008-A-07742, Vienna, 2008.

Winer, A. M. and Biermann, H. W.: Long pathlength differential optical absorption spectroscopy (DOAS) measurements of gaseous $\mathrm{HONO}, \mathrm{NO}_{2}$ and $\mathrm{HCHO}$ in the California south coast air basin, Res. Chem. Intermediat., 20, 423-445, 1994. 2029

Wulfmeyer, V. and Behrendt, A., Convective and Orographically induced Precipitation Study, http://cops.uni-hohenheim.de/, 2008

Zhou, X. L., Civerolo, K., Dai, H. P., Huang, G., Schwab, J., and Demerjian, K.: Summertime nitrous acid chemistry in the atmospheric boundary layer at a rural site in New York State, J. Geophys. Res., 107 (D21), 4590, doi:10.1029/2001JD001539, 2002.

\section{Development and application of a new mobile LOPAP instrument}

R. Häseler et al.

\section{Title Page}

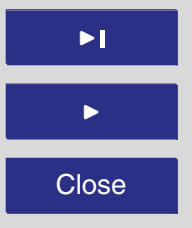

Full Screen / Esc

Printer-friendly Version

Interactive Discussion 
Table 1. List of all flights (ZEPTER-1, 2007) with measurements of HONO by the new LOPAP-Z instrument. VP: vertical profiles, IT: instrument tests, EE: entrainment experiment, and TF: transfer flights ( ${ }^{a}$ : Transfer from airport Friedrichshafen, FDH, to Baden Airpark, FKB. ${ }^{\text {b }}$ : Transfer from FKB to FDH). Cabin layouts: CL4: reduced set of instruments for test $\left(\mathrm{HO}_{\mathrm{x}}, \mathrm{NO}_{\mathrm{x}}\right.$, $\mathrm{O}_{3}, \mathrm{HONO}$, photolysis frequencies, and MaxDOAS), CL3: CL4 plus $\mathrm{HCHO}$ and filter sampling, CL2: CL4 plus CO and VOC, CL1: full set of instruments (CL4 plus $\mathrm{HCHO}$, filter sampling, CO, VOC, and isotopes).

\begin{tabular}{lclccccc}
\hline $\begin{array}{c}\text { Date } \\
\text { 2008 }\end{array}$ & $\begin{array}{c}\text { Flight } \\
\#\end{array}$ & Location & $\begin{array}{c}\text { Start } \\
\text { UTC }\end{array}$ & $\begin{array}{c}\text { End } \\
\text { UTC }\end{array}$ & $\begin{array}{c}\text { Ceiling } \\
\text { [m] (AGL) }\end{array}$ & $\begin{array}{l}\text { flight } \\
\text { design }\end{array}$ & $\begin{array}{c}\text { cabin } \\
\text { layout }\end{array}$ \\
\hline 16 Jul & F02 & Lake Constance & $12: 15$ & $13: 57$ & 563 & VP & CL1 \\
16 Jul & F03 & Lake Constance & $14: 45$ & $16: 49$ & 596 & VP & CL1 \\
17 Jul & F05 & Lake Constance & $14: 05$ & $18: 35$ & 737 & VP, IT & CL2 \\
18 Jul & F06 & Lake Constance & $08: 01$ & $09: 00$ & 953 & VP & CL1 \\
18 Jul & F07 & Lake Constance & $15: 50$ & $17: 19$ & 558 & VP, IT & CL1 \\
20 Jul & F08 & Lake Constance $^{1}$ Jul & F09:35 & $05: 45$ & 650 & VP & CL3 \\
21 Jul & F10 & Take Constance $^{\text {a }}$ & $04: 10$ & $05: 45$ & 640 & VP,IT & CL3 \\
21 Jul & F11 & Bienwald & $11: 50$ & $14: 29$ & 554 & TF & CL3 \\
23 Jul & F12 & Murgtal & $15: 04$ & $16: 45$ & 832 & VP & CL3 \\
23 Jul & F13 & Murgtal & $04: 15$ & $08: 50$ & 499 & EE, VP & CL1 \\
25 Jul & F14 & Bienwald & $04: 45$ & $16: 49$ & 530 & EE, VP & CL1 \\
25 Jul & F16 & Karlsruhe, Bienwald & $13: 24$ & $18: 25$ & 471 & VP & CL1 \\
26 Jul & F17 & Bienwald & $04: 12$ & $07: 29$ & 649 & VP, VP & CL1 \\
26 Jul & F18 & Tranfer $^{b}$ & $07: 52$ & $11: 35$ & 518 & TF & CL1 \\
\hline
\end{tabular}

2, 2027-2054, 2009

\section{Development and application of a new mobile LOPAP instrument}

R. Häseler et al.

\section{Title Page}

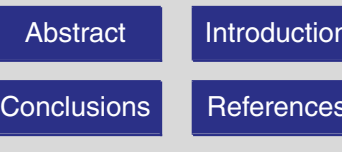

Tables Figures
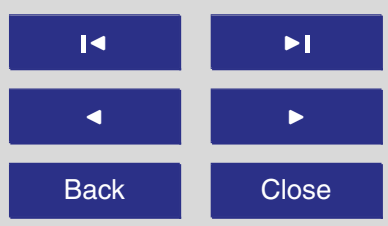

Full Screen / Esc

Printer-friendly Version

Interactive Discussion 
Table 2. List of all flights (ZEPTER-2, 2008) with measurements of HONO by the LOPAP-Z instrument. All flights were carried out stating at Friedrichshafen (FDH). VP: vertical profiles, CLF: constant layer flights. Cabin layouts: CL4: reduced set of instruments for test $\left(\mathrm{HO}_{\mathrm{x}}, \mathrm{NO}_{\mathrm{x}}\right.$, $\mathrm{O}_{3}, \mathrm{HONO}$ and photolysis frequencies and MaxDOAS), CL1: full set of instruments (CL4 plus $\mathrm{CO}, \mathrm{HCHO}, \mathrm{VOC}, \mathrm{CPC}$, and SMPS).

\begin{tabular}{|c|c|c|c|c|c|c|c|}
\hline $\begin{array}{l}\text { Date } \\
2008\end{array}$ & $\begin{array}{c}\text { Flight } \\
\#\end{array}$ & Location & $\begin{array}{l}\text { Start } \\
\text { UTC }\end{array}$ & $\begin{array}{l}\text { End } \\
\text { UTC }\end{array}$ & $\begin{array}{c}\text { Ceiling } \\
\text { [m] (AGL) }\end{array}$ & $\begin{array}{l}\text { flight } \\
\text { design }\end{array}$ & $\begin{array}{l}\text { cabin } \\
\text { layout }\end{array}$ \\
\hline 17 Oct & F01 & Lake Constance & $17: 20$ & 19:32 & 916 & VP & CL4 \\
\hline 18 Oct & F02 & Lake Constance & $09: 45$ & $14: 08$ & 821 & VP & CL4 \\
\hline 18 Oct & F03 & Lake Constance & $14: 11$ & $17: 45$ & 768 & VP & CL4 \\
\hline 19 Oct & F04 & Ravensburg, Altdorfer Forest & $08: 45$ & $13: 25$ & 688 & VP & CL4 \\
\hline 19 Oct & F05 & Ravensburg, Altdorfer Forest & $13: 42$ & $17: 36$ & 784 & VP & CL4 \\
\hline 20 Oct & F06 & Lake Constance & $04: 43$ & $10: 50$ & 840 & VP & CL4 \\
\hline 20 Oct & F07 & Lake Constance & $11: 26$ & $17: 18$ & 785 & VP & CL4 \\
\hline 24 Oct & F08 & Lake Constance & $14: 38$ & $18: 08$ & 1003 & VP & CL1 \\
\hline 25 Oct & F09 & Lake Constance & $13: 20$ & $16: 44$ & 1002 & VP & CL1 \\
\hline 26 Oct & F10 & Altdorfer Forest & $12: 40$ & 17:01 & 795 & VP & CL1 \\
\hline 26 Oct & F11 & Altdorfer Forest & $17: 40$ & $20: 45$ & 945 & VP & CL1 \\
\hline 31 Oct & F13 & Lake Constance & $15: 04$ & 17:54 & 784 & CLF & CL1 \\
\hline $2 \mathrm{Nov}$ & F14 & Tettnanger Forest & $11: 02$ & 14:31 & 597 & CLF & CL1 \\
\hline $2 \mathrm{Nov}$ & F15 & Tettnanger Forest & $15: 15$ & $17: 57$ & 389 & CLF & CL1 \\
\hline $3 \mathrm{Nov}$ & F16 & Ravensburg, Altdorfer Forest & $10: 07$ & $13: 40$ & 566 & VP & CL1 \\
\hline $3 \mathrm{Nov}$ & F17 & Ravensburg, Altdorfer Forest & $14: 10$ & $17: 37$ & 663 & VP & CL1 \\
\hline $3 \mathrm{Nov}$ & F18 & Ravensburg, Altdorfer Forest & $18: 01$ & $20: 59$ & 695 & VP & CL1 \\
\hline $5 \mathrm{Nov}$ & F19 & Hinterland of Lake Constance & $10: 44$ & $14: 31$ & 525 & CLF, VP & CL1 \\
\hline $5 \mathrm{Nov}$ & F20 & Lake Constance & $15: 50$ & $20: 28$ & 391 & CLF & CL1 \\
\hline $7 \mathrm{Nov}$ & F21 & Hinterland of Lake Constance & 09:09 & 13:25 & 1001 & CLF, VP & CL1 \\
\hline $7 \mathrm{Nov}$ & F22 & Hinterland of Lake Constance & 15:07 & $16: 40$ & 899 & CLF, VP & CL1 \\
\hline $8 \mathrm{Nov}$ & F24 & Hinterland of Lake Constance & $11: 09$ & $14: 14$ & 933 & CLF, VP & CL1 \\
\hline $8 \mathrm{Nov}$ & F25 & Lake Constance & $14: 33$ & $17: 19$ & 890 & VP & CL1 \\
\hline
\end{tabular}

\section{Development and application of a new mobile LOPAP instrument}

R. Häseler et al.

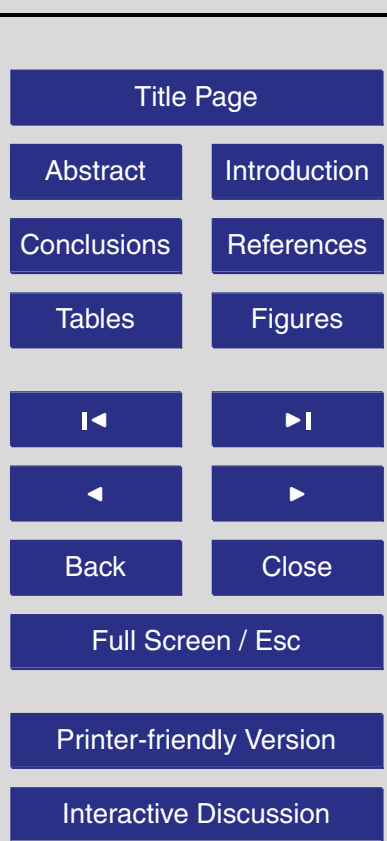




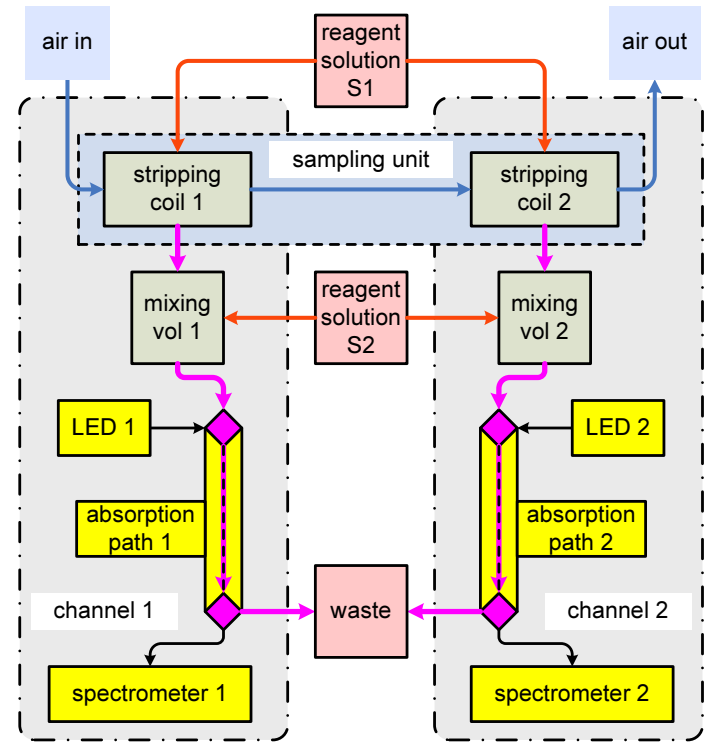

Fig. 1. Flow scheme of a LOPAP instrument (after Heland et al., 2001): air (blue) is sampled into two stripping coils which are operated in series. In both coils the air is exposed to equal flows of solution S1 which are separately transferred into two mixing volumes where reagent solution S2 is added. The liquids are pumped through two teflon tubings which work as liquid core waveguides (LCW). Light from white light LEDs is coupled into the LCWs and the absorption spectrum of each channel is monitored by a spectrometer.

\section{Development and application of a new mobile LOPAP instrument}

R. Häseler et al.

\section{Title Page}

Abstract Introduction

Conclusions

References

Tables

Figures

14

4

Back

Close

Full Screen / Esc

Printer-friendly Version

Interactive Discussion 


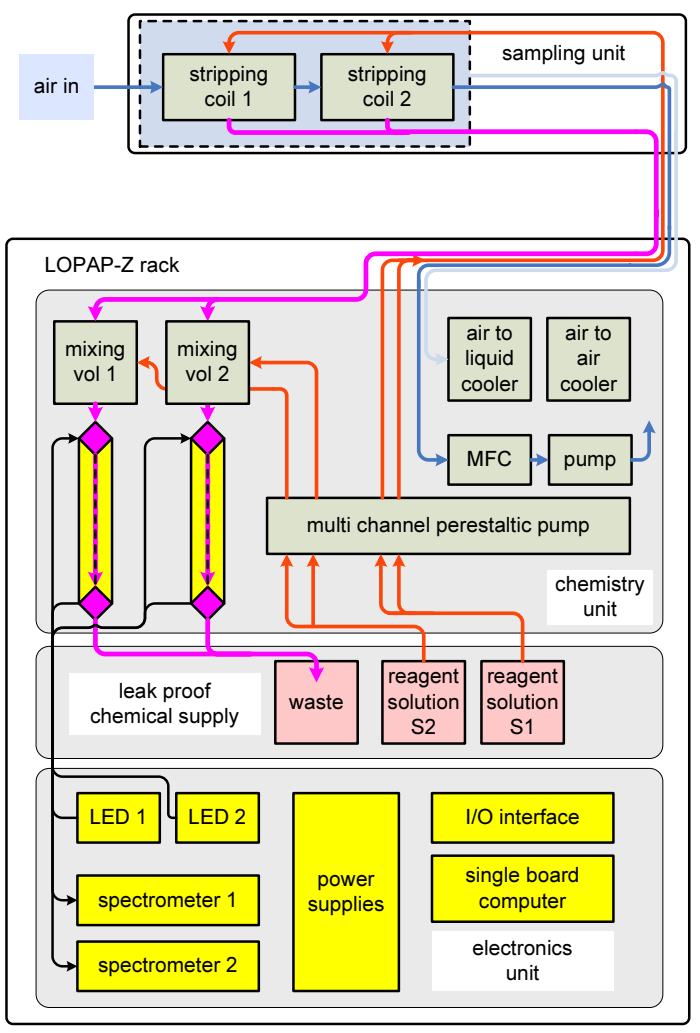

Fig. 2. Setup of the LOPAP-Z: the rack consists of 3 separate, enclosed units. Only in the upper two (chemistry and supply) wet chemicals and gases are processed. The lower, electronic unit cannot be exposed to chemicals. Colors and components are identical to Fig. 1.
AMTD

2, 2027-2054, 2009

\section{Development and application of a new mobile LOPAP instrument}

R. Häseler et al.

\section{Title Page}

Abstract

Introduction

Conclusions

References

Tables

Figures

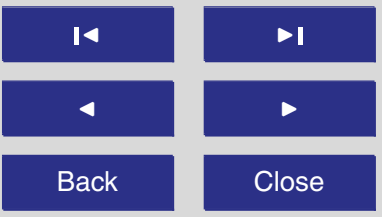

Full Screen / Esc

Printer-friendly Version

Interactive Discussion 
AMTD

2, 2027-2054, 2009

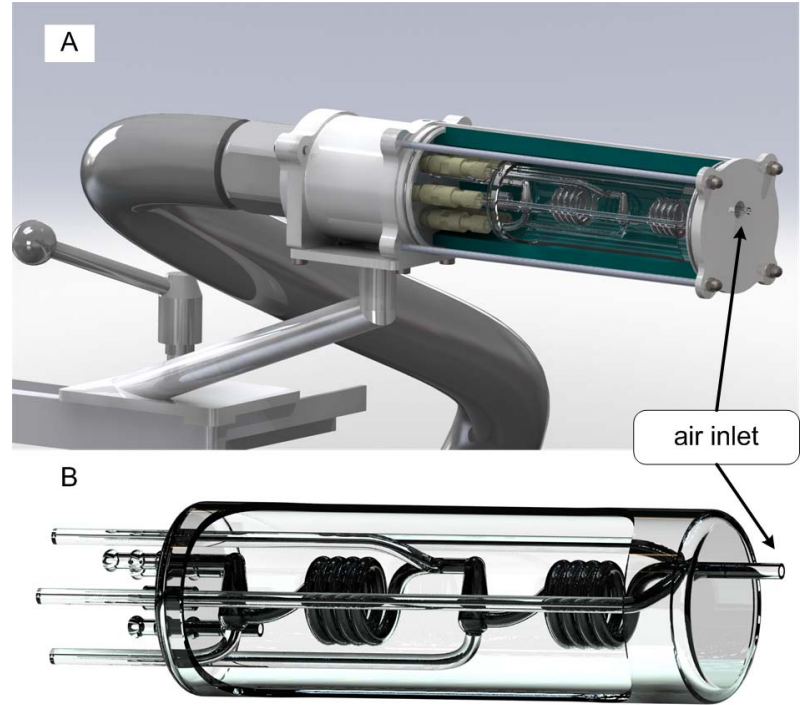

Development and application of a new mobile LOPAP instrument

R. Häseler et al.

\section{Title Page}

Abstract

Introduction

Conclusions

References

Tables

Figures

14

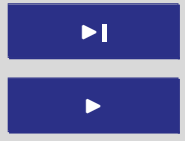

Fig. 3. New ruggedized sampling unit. A: cut away view of entire sampling unit. B: glass cylinder with stripping coils.

\section{Close}

Full Screen / Esc

Printer-friendly Version

Interactive Discussion 


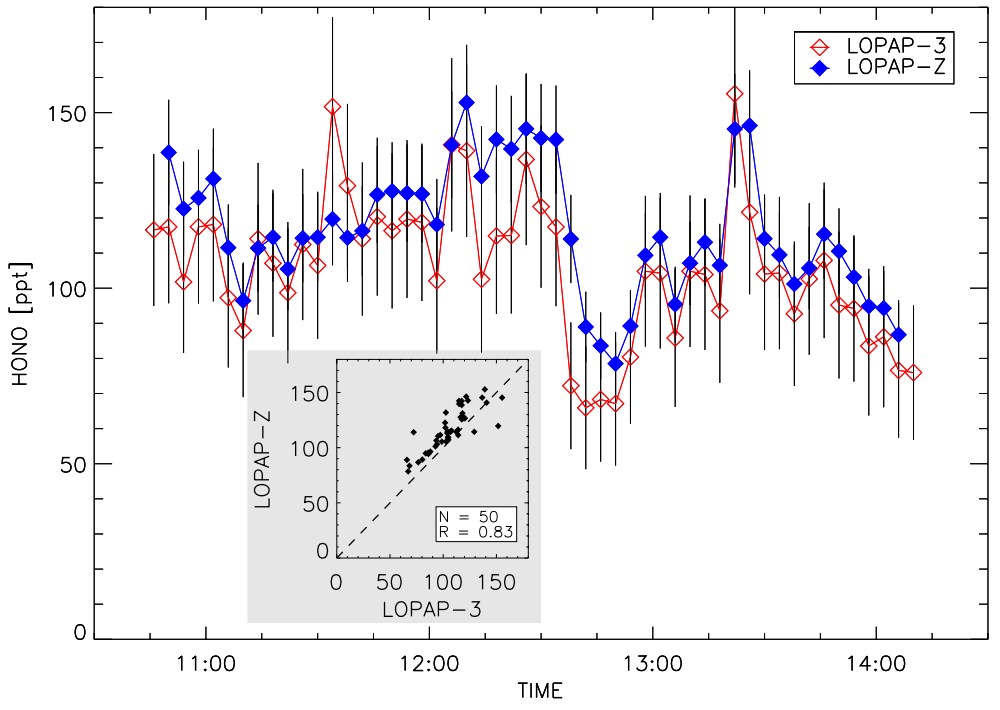

Fig. 4. Laboratory intercomparison of a LOPAP-3 instrument and the new LOPAP-Z instrument. The instruments were connected to a common inlet line sampling ambient air just outside the window of the laboratory. The airflow was split via a teflon T-piece into both sampling units. The inset shows the same data as correlation.

\section{Development and application of a new mobile LOPAP instrument}

R. Häseler et al.

\section{Title Page}

Abstract Introduction

Conclusions

References

Tables

Figures

14 $>1$

4

Back

Close

Full Screen / Esc

Printer-friendly Version

Interactive Discussion 


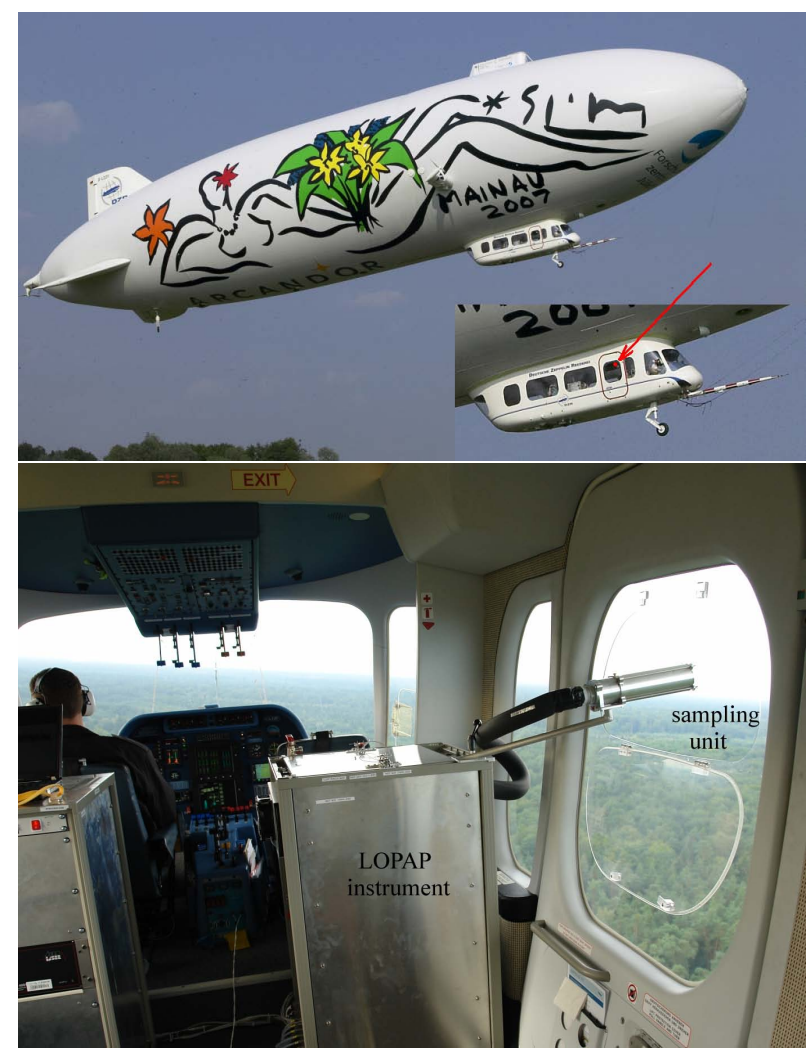

AMTD

2, 2027-2054, 2009

\section{Development and application of a new mobile LOPAP instrument}

R. Häseler et al.

\section{Title Page}

Abstract

Conclusions

Tables

14

4

Back

Full Screen / Esc

Fig. 5. Upper: Outside view of the Zeppelin NT airship during take-off. The arrow in the enlarged detail view denotes the location of the LOPAP-Z inlet. Lower: setup of the LOPAP-Z instrument aboard the Zeppelin NT airship during flight. The sampling unit sticks out of the window in the front door of the gondola, the inlet is approximately $20 \mathrm{~cm}$ from the surface of the gondola. The rack is mounted to the floor replacing one passenger seat.

Printer-friendly Version

Interactive Discussion
Introduction

References

Figures

$>1$

Close 

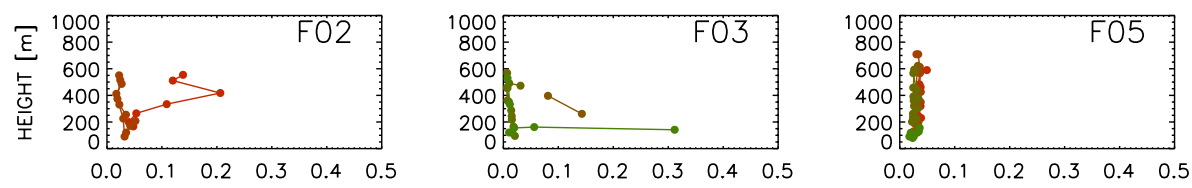

AMTD
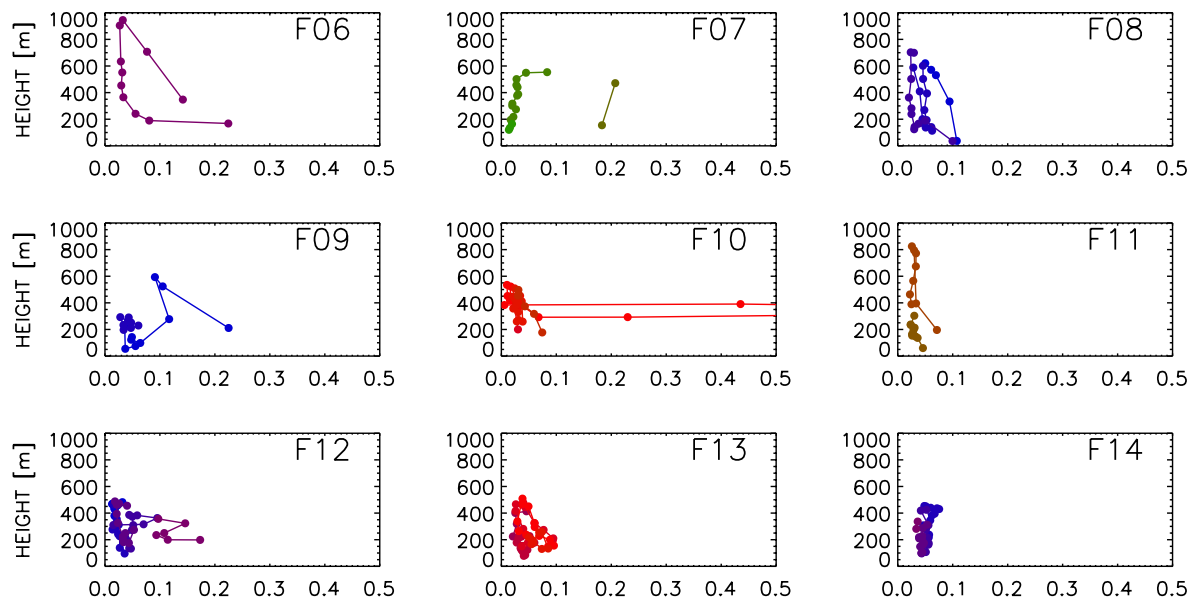

Title Page
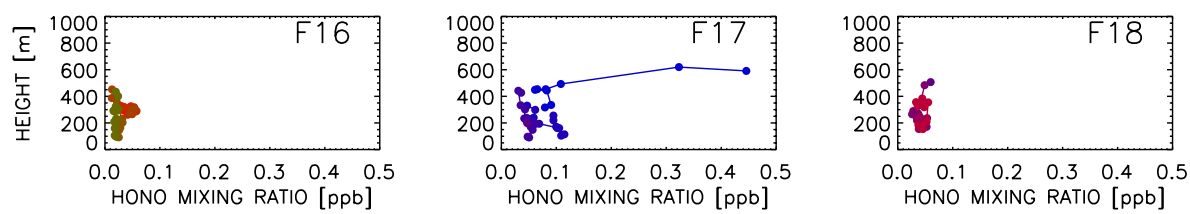

TIME OF DAY $[h]$

Fig. 6. Single altitude profiles of all measured HONO data during the ZEPTER-1 campaign, July 2007. The color code refers to the daytime, for flight numbers and locations see Table 1.

Printer-friendly Version

Interactive Discussion 


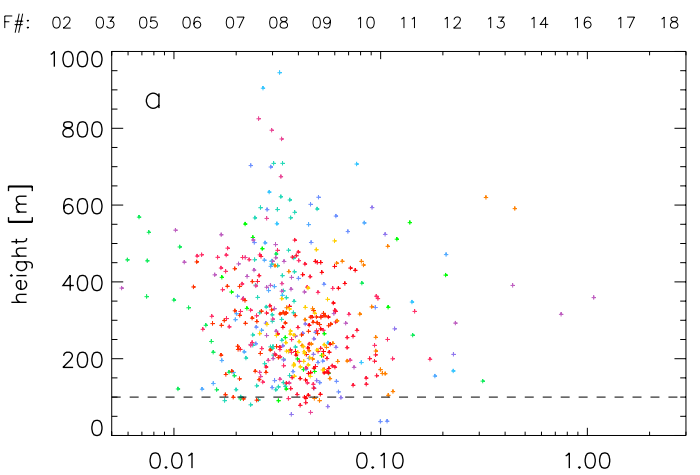

AMTD

2, 2027-2054, 2009

\section{Development and application of a new mobile LOPAP instrument}

R. Häseler et al.

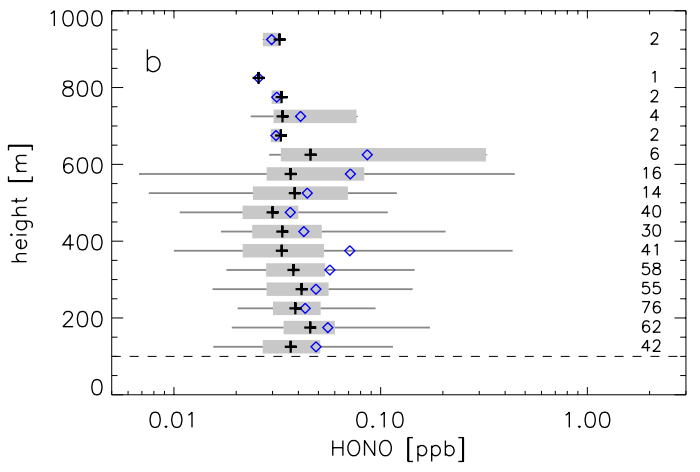

Title Page

Abstract Introduction

Conclusions

References

Tables

Figures
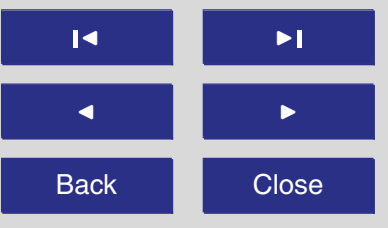

Fig. 7. Altitude profile of all measured HONO data during the ZEPTER-1 campaign, July 2007. (a): all single data points versus height (above ground). The color code represents the flight number given in Table 1. (b): box-whisker diagram of the data grouped in $50 \mathrm{~m}$ intervals. The numbers indicate the number of original data points in this group. The + is the median, boxes represent $50 \%$, the whiskers $90 \%$ of the data. The blue diamond is the average. 

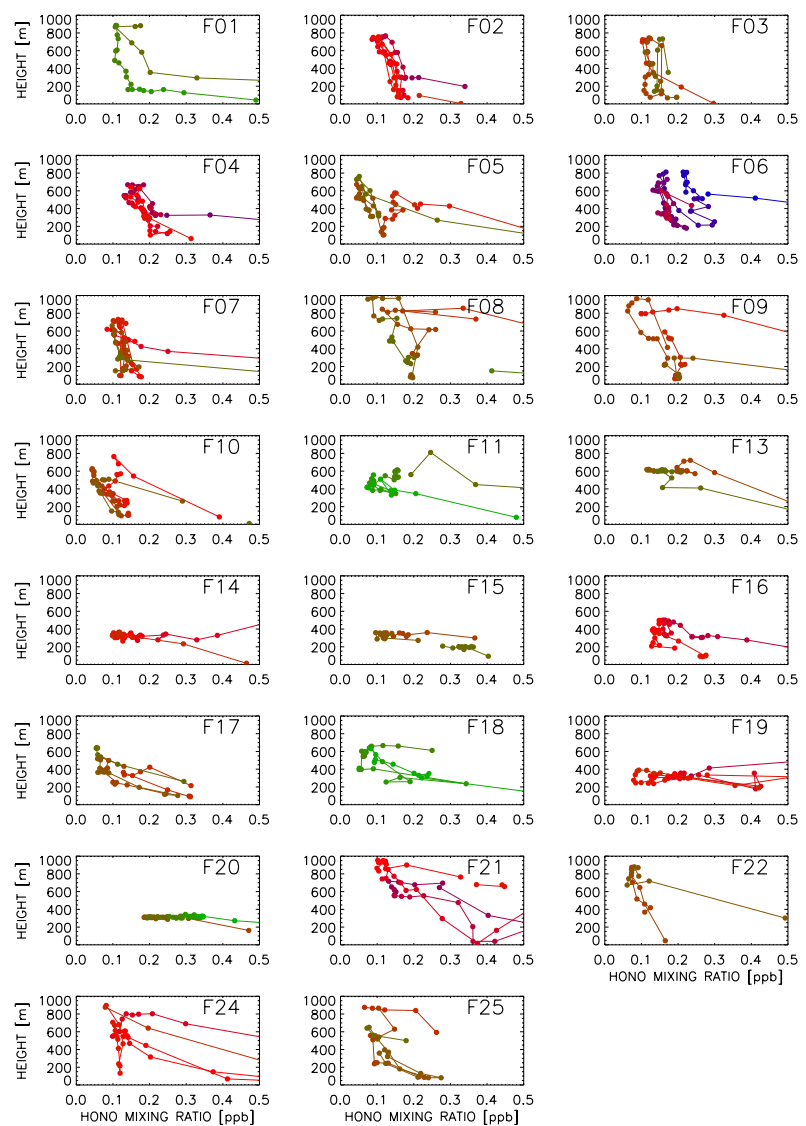

TIME OF DAY [h]
AMTD

2, 2027-2054, 2009

\section{Development and} application of a new mobile LOPAP instrument

R. Häseler et al.

\section{Title Page}

Abstract

Introduction

Conclusions

References

Tables

Figures

14

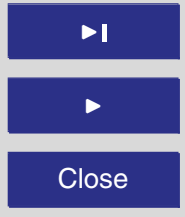

Back

Full Screen / Esc

Printer-friendly Version

Interactive Discussion

Fig. 8. Single altitude profiles of all measured HONO data during the ZEPTER-2 campaign, July 2008. The color code refers to the daytime, for flight numbers and locations see Table 2. 


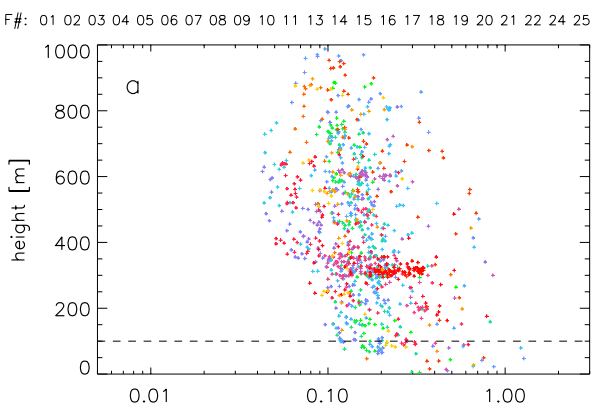

\section{2, 2027-2054, 2009}

\section{Development and application of a new mobile LOPAP instrument}

R. Häseler et al.

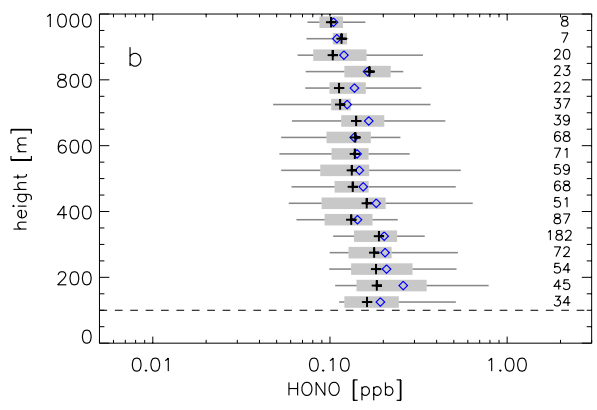

Title Page

Abstract

Conclusions

Tables

14

4

Back

Full Screen / Esc

Printer-friendly Version

Interactive Discussion 
AMTD

2, 2027-2054, 2009

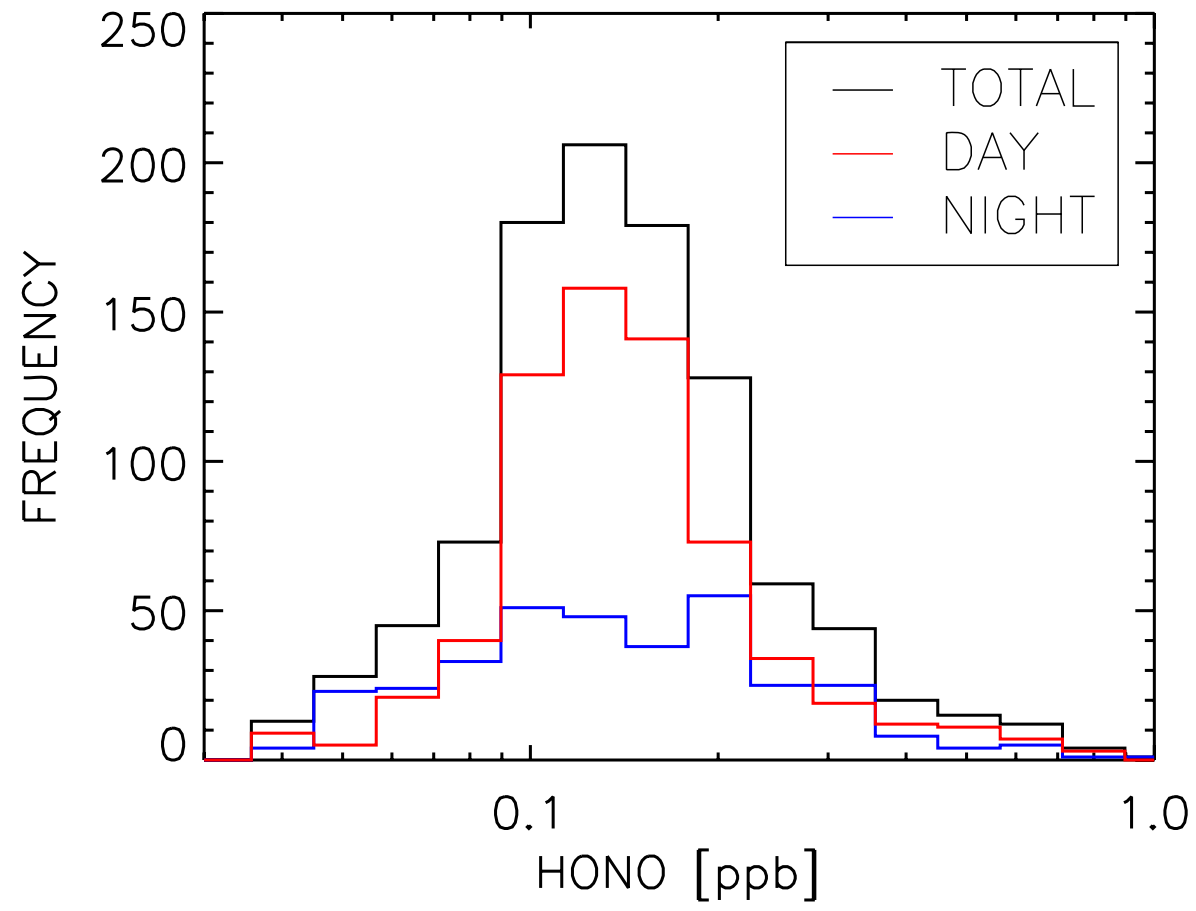

Fig. 10. Frequency distribution of HONO measurements of all flights in 2008 (Zepter-2) separated by day $\left(\mathrm{SZA}<90^{\circ}\right)$ and night.

\section{Development and application of a new mobile LOPAP instrument \\ R. Häseler et al.}

Title Page

Abstract

Introduction

Conclusions

References

Tables

Figures

14

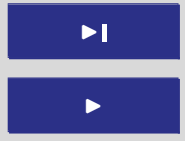

Back

Close

Full Screen / Esc

Printer-friendly Version

Interactive Discussion 